\title{
Media work, identity, and the motivations that shape branding practices among journalists: An explanatory framework
}

new media \& society 2019, Vol. 21 (4) 836-855 (C) The Author(s) 2018 Article reuse guidelines: sagepub.com/journals-permissions DOI: I0.1 I77/|46|4448|8809392 journals.sagepub.com/home/nms

(S)AGE

\section{Logan Molyneux}

Temple University, USA

\section{Seth C Lewis}

University of Oregon, USA

\section{Avery E Holton}

The University of Utah, USA

\begin{abstract}
This study offers a new way of understanding the motivations that influence media workers' impression management (or branding) in the social media era. Amid the growing insecurity of media work generally and the particular pressures of branding oneself and promoting one's employer online, our research introduces a framework through which to interpret the forces and factors-internal (social-psychological) and external (environmental) - that shape how and why media professionals engage in branding. Through a first-of-its-kind survey of a broad cross-section of journalists $(N=642)$, this study proposes, tests, and confirms a branding alignment hypothesis. This typology sheds light on how branding activity aligns with individual, organizational, and institutional motivations as well as professional identities. Importantly, the study shows how branding is manifested over and above social media dynamics alone and reveals how "self-made" and "company" journalists differ in how they promote themselves, their employers, and the journalism occupation.
\end{abstract}

\section{Corresponding author:}

Logan Molyneux, Temple University, 2020 N. 13 ${ }^{\text {th }}$ Street, Philadelphia, PA 19122, USA.

Email: logan@temple.edu 


\section{Keywords}

Branding, branding alignment hypothesis, impression management, journalism, media work, motivations, personal branding, social media

Media work, and what it means to be a media worker, has changed profoundly in the $21 \mathrm{st}$ century. Among these shifts is an ongoing transition, in society at large and in the culture industries especially, away from stable, career-sustaining employment and toward a gig economy marked by lower pay, fewer fringe benefits, and a higher degree of uncertainty. While punishing hours, precarious working conditions, and structural inequalities have long characterized media and creative work (Deuze, 2007; Gill, 2010; Hesmondhalgh and Baker, 2011), today's workers face intensified challenges in a digital and social media world that demands always-on connectivity. In addition to making media for a growing array of platforms, they also feel obligated "to respond to the exigencies of social media" by, for example, continuously monitoring and developing an online presence (or brand) for themselves, their employers, or both (Duffy and Schwartz, 2017: 2). Indicative of this direction and capturing the state of affairs in the fast-growing realm of social media labor, Duffy and Schwartz (2017) argue that "employers construct [social media] workers through a patterned set of features, including sociability, deft emotional management, and flexibility," and that these "industrial imaginings incite workers to remain ever available, juggle various roles and responsibilities, and engage in persistent emotional labor - both online and off' (p. 1, emphasis original).

Among media industries, journalism has been particularly influenced by such digital demands and occupational upheaval (Deuze and Witschge, 2018; Lewis, 2012). Contemporary news work is marked by a growing degree of urgency, anxiety, and destabilization, and in such an environment, many journalists feel compelled to self-promote and build their brand - or actively market their employer's image - to maintain relevance and thus keep their job or secure a new one (Bunce, 2017; Ekdale et al., 2015; Tandoc and Oh, 2017). Social media amplify these anxieties and extend them to all users, not just media workers, leading to a constant re-evaluation of one's professional and personal identities, challenging people to develop more a more fluid sense of self (Rettberg, 2014, 2018). As such, the presentation of self, or impression management, has become an ambient, everyday requirement for many, made all the more complicated, as people represent their identities in light of perceived norms around race, class, gender, and more (Pitcan et al., 2018). At the same time, social media represent but one space in which identity is performed. As this study shows, to fully contextualize the nature of branding in media work today requires looking beyond discrete practices on social media so thoroughly studied already (Hanusch and Bruns, 2017; Molyneux et al., 2017; Sacco and Bossio, 2017) to consider a broader set of forces and factors that may shape how and why certain forms of impression management occur.

The case of journalists, therefore, offers a particular vantage point for studying converging trends in media work and identity work. This study makes several contributions to these literatures. Conceptually, it synthesizes previous research to develop a typology for understanding branding motivations and tests the validity of this framework by introducing and evaluating a branding alignment hypothesis. The typology and the hypothesis 
that tests it shed new light on how certain branding approaches match up with individual, organizational, and institutional types of motivation and influence. Methodologically, this study tests and confirms the branding alignment hypothesis through newly developed measures and a first-of-its-kind survey of journalistic branding, drawing on a diverse sample of journalists $(N=642)$ in North America. In addition, by controlling for journalists' use of social media and relative presence on Twitter, this study is able to assess branding motivations and actions apart from social media dynamics alone. Notably, among other things, this study finds that "self-made journalists" (as classified here) seek recognition and job security by promoting themselves rather than co-workers, whereas "company journalists" regard their organization as the focus of attention, promoting co-workers rather than journalists and media workers at other organizations. This split in identification, manifest where motivations align with practices, provides a new pathway for studying branding in journalism as well as media work generally.

\section{Literature review}

The fact that journalists engage in personal branding and other forms of promotional work is by now a taken-for-granted notion of contemporary journalism. Indeed, such branding activity is a hallmark of digital work (Gandini, 2016) and can be interpreted as a natural consequence of the precarity and contingency that have marked media work in the 21st century (Deuze, 2007; Powers and Vera Zambrano, 2018), a period in which workers in the broader cultural industries have sought to mitigate the growing precarity of their work (Banks and Hesmondhalgh, 2009; Marwick, 2013). Branding is evident at various levels across the social media pages of journalists who regularly engage in promoting themselves, their colleagues, their organizations, and the wider profession of journalism (Molyneux et al., 2017; Ottovordemgentschenfelde, 2017; Sacco and Bossio, 2017). A growing body of research has highlighted the nature and evolution of this journalistic branding, particularly as journalists' personal interests come into conflict with organizational prerogatives. Journalists, for example, see social media as an opportunity to grow their following, develop relationships, and gain recognition, but they struggle to find the right balance between being personally relatable to their audiences and simultaneously professionally representative of their organization (Brems et al., 2017; Hanusch and Bruns, 2017). While previous studies have used interviews to explore what journalists think about branding and content analyses to examine what they are actually doing, a critical gap has emerged: research has yet to capture in a systematic fashion, across a broad cross-section of journalists, exactly why journalists are engaging in certain branding activities and who or what may be influencing such behaviors.

Understanding how and why journalists represent themselves, their organizations, and their profession (or institution) contributes to the broader social construction of journalism and its boundaries, shaping perceptions about who journalists are, what they do, and where they fit vis-à-vis audiences (Carlson and Lewis, 2015). Branding may play out in different ways across different levels of concern (e.g. individual, organizational, or institutional) and according to different personal orientations and motivations. But some of these distinctions about an individual journalists' context or personal/professional circumstance have largely been lost in research that has all but equated 
journalistic branding activity with social media activity. While it is obvious that social media is a key space - indeed, perhaps the space - for self-promotion and other branding expressions, it is necessary to disentangle the two and draw a more holistic picture of how and why journalists might engage in such practices. In particular, research has yet to tease out the complex intersection of environmental factors (such as one's organizational arrangement) and social-psychological factors (such as one's self-expressed professional identity and motivations) and how they might influence various levels and functions of branding.

At the heart of these questions is the journalist's professional identity, often described as an ideology or set of values that distinguishes journalists from other professionals (Deuze, 2005). These values are held most strongly at an institutional level, though journalists also identify strongly with their organizations (Russo, 1998); a natural third category would be the individual, especially given the increase in freelancing and entrepreneurial forms of journalism (Deuze and Witschge, 2018). While this study does not investigate the values themselves or probe specific elements of professional identity, it is important for the study of journalistic branding to know how this professional identity derives. Its origin may also be a point of origin for branding practices aligned at institutional, organizational, or individual levels.

\section{Branding motivations}

The question of what motivates journalists to perform a certain action is nearly as old as the field of communication studies itself. Scholars have previously identified social control, forces of professionalization, norms of objectivity, gatekeeping, boundary work, and conceptualizations of journalism's role in a democracy (to name a few) as factors influencing journalism's work (Berkowitz, 1997; Carlson and Lewis, 2015; Deuze, 2007; Lewis, 2012; Singer, 2015). Journalists respond to overlapping spheres of influence, which may be arranged in a hierarchy from the individual to macro-social systems (Shoemaker and Reese, 2013). Several of these might be sources of influence on journalistic branding, beginning with an individual desire to be recognized or to stabilize one's standing within the field. At the level of routine practices, journalists may notice other journalists developing followings online or seeking to stand out among their peers and thus adopt this as a standard practice (Hedman, 2015). At the level of the organization, a journalist's supervisors or corporate leaders may instruct them to promote their work or that of the organization, and many have given precisely this directive (Holton and Molyneux, 2017). Finally, at the level of social institutions, journalists may perceive their profession as being under attack and so seek to defend it by building up journalism as a vital part of society through positive portrayals of the work and people that best exemplify professional journalism (Carlson and Lewis, 2015; Molyneux and Holton, 2015; Singer, 2015). These levels of branding activity (individual, organizational, and institutional) have been studied in previous work.

The organizational directive to participate in branding may be overt, codified in social media policies now commonly in place at media outlets worldwide. But additional influence may be more subtle, in the form of social control, as long ago documented by Breed (1955). In recent years, journalism as a profession has developed a 
particular affinity for technology (Creech and Nadler, 2017), seeking to adopt virtually all its forms in news creation and distribution, as well as praising and rewarding those who best employ it in their work (Lewis and Zamith, 2017). Seeing this, journalists may seek to replicate the successes and avoid the failures of other journalists on social media, perpetuating a sense that specific forms of social media use (branding among them) are inherently journalistic and vital to proper execution of the profession. This, of course, builds upon trends toward professionalization that have pushed journalists to adopt other conventions as journalistic practice (e.g. data journalism, fact-checking, audience analytics, and so on). Previous work suggests that professional approaches to branding are overtaking personal ones, even in ostensibly personal and authentic channels such as social media (Lough et al., 2018).

Journalists now seek to establish themselves as experts in the area that they cover and gain an online following that will stay with them even if they change jobs. This derives in part from media trends described earlier that are destabilizing employment but is particularly felt in countries where journalism has a more commercial orientation. One comparison found that American journalists developed personal brands much more often than their French counterparts, likely owing to differences in relative commercialization of the press in those two countries (Powers and Vera-Zambrano, 2018). Previous work has examined journalists' efforts to defend the boundaries of their profession (Carlson, 2017; Lewis, 2012; Singer, 2015). This boundary work is particularly important in understanding the institutional level of branding, wherein journalists forge connections with their peers at competing outlets as a way of strengthening the profession overall, as it faces cultural and economic weakness. But it has become even more pronounced recently, as journalists fend off accusations against their work (e.g. of carelessly misrepresenting the world or even deliberately manipulating the story) or outright dismissals of journalism as a whole as "fake news."

In addition to these possible explanations, previous work on journalistic branding has identified additional factors. Developing a brand may be an attempt to create and assert editorial capital, a specific form of resources inherent in skills and networks (Bourdieu, 1986; Schultz, 2007). This capital can then be leveraged when courting audiences or potential employers. Journalists have said that their audiences call for more intimate connections through journalists' sharing of personal information, humor, and opinion (Brems et al., 2017; Hedman, 2017; Molyneux and Holton, 2015). This audience-focused work is often called engagement, though the term also has other meanings (Nelson, 2018). Journalists' outreach on social media also has a marketing motivation (Tandoc and Vos, 2016), which is simply to attract attention to themselves, their work, and their organization. Finally, journalists have said they use personal branding as a way of maintaining connections to, and possibly supporting, other journalists as peers in their professional field (Molyneux and Holton, 2015).

\section{Branding alignment}

Considering the potential motivations identified here, a typology of branding motivations has begun to emerge (Table 1). This typology is structured around two key divisions that represent tensions in branding practice observed in previous studies. First, a 
Table I. Typology of branding motivations by approach and level.

\begin{tabular}{|c|c|c|c|c|}
\hline & & \multicolumn{3}{|l|}{ Branding level } \\
\hline & & Individual & Organizational & Institutional \\
\hline \multirow{2}{*}{$\begin{array}{l}\frac{5}{0} \\
\frac{0}{2} \\
\frac{0}{2} \\
\frac{1}{4}\end{array}$} & $\begin{array}{l}\text { Personal } \\
\text { motivations }\end{array}$ & $\begin{array}{l}\text { - } \text { Gain respect and } \\
\text { renown } \\
\text { - } \text { Develop } \\
\text { relationships }\end{array}$ & $\begin{array}{l}\text { - Collegiality with } \\
\text { co-workers }\end{array}$ & $\begin{array}{l}\text { - Support other } \\
\text { journalists } \\
\text { (solidarity under } \\
\text { pressure) } \\
\text { - Encourage } \\
\text { collaboration }\end{array}$ \\
\hline & $\begin{array}{l}\text { Professional } \\
\text { motivations }\end{array}$ & $\begin{array}{l}\text { - Preserve my job } \\
\text { - Grow my } \\
\text { following } \\
\text { - Increase my value }\end{array}$ & $\begin{array}{l}\text { - Please my boss } \\
\text { - Adhere to policy } \\
\text { - Attract attention } \\
\text { to org } \\
\text { - Promote co-workers }\end{array}$ & $\begin{array}{l}\text { - Uphold journalistic } \\
\text { values } \\
\text { - Promote other } \\
\text { journalists }\end{array}$ \\
\hline
\end{tabular}

division in approach separates the personal and the professional, treating more relational motivations as personal and more transactional motivations as professional. As previous literature has shown, these two realms are increasingly blurry in practice, but the distinction is both conceptually and methodologically useful here. The second division is among the levels at which the branding activity is intended to operate (i.e. individual, organizational, or institutional) or the branding target. These three branding targets have been identified in previous studies as distinct foci of branding attention and practice. Essentially, they address elements of credibility-Am I to be trusted because of who I am? Or because of who I work for? Or simply because of my profession? - and control-Who is in charge here, me or my employer? Each cell in Table 1 offers a distinct grouping of possible motivations. Personal motivations at the individual level may be driven by a want to gain respect and develop relationships, while professional motivations at the same level may be centered on preserving one's job and increasing one's marketability. Collegiality with co-workers might be a personal motivation aimed at the organizational level, while an adherence to superiors and policies and promoting coworkers might constitute professional motivations. Institutionally, journalists might be personally motivated to support other journalists and encourage collaboration and professionally driven to uphold journalistic values and maintain journalistic authority.

These motivations and the typology by which they are classified are drawn largely from an emerging body of research that has relied, for the most part, on content analyses of Twitter (Hanusch and Bruns, 2017; Lough et al., 2018; Molyneux et al., 2017; Ottovordemgentschenfelde, 2017) or feedback from journalists limited to a single social media platform (Hedman, 2017; Holton and Molyneux, 2017; Molyneux and Holton, 2015). To look beyond Twitter alone, this study considers multiple social media platforms used by journalists, ${ }^{1}$ the use of social media in their branding activities, the possible relationship between their professional identity and their use of branding, and whether or not the motives behind that branding activity align with the kind of branding they practice. Thus, this study addresses the following overarching research question: 
$\boldsymbol{R Q 1 . ~ W h a t ~ m o t i v a t e s ~ p r o f e s s i o n a l ~ j o u r n a l i s t s ' ~ u s e ~ o f ~ b r a n d i n g ? ~}$

Content analyses of journalists' branding activities have described journalists' branding activities at three broad levels: individual, organizational, and institutional. This pattern could be shaped by external influences (the celebrity-oriented nature of social media, organizational pressure, and the cultural weakening of journalistic institutions), but we suspect it is also a product of internal influences, specifically identity and motivations. While many journalists have reported practicing branding at multiple levels, sensing the conflict between individual and organizational branding most strongly, previous analyses also noted that journalists tend to favor one of these approaches, applying it consistently across their profiles (Lough et al., 2018). Therefore, we propose that journalists' branding activity may be driven primarily by internal factors that are individually and uniquely felt, rather than by commonly felt external pressures from social media norms, journalistic practices, or organizational mandates (which have begun to converge). We measure these internal factors by asking journalists about the foundations of their professional identity and about the motivations identified in Table 1. Thus, the following two hypotheses can be understood as two ways of testing an overall branding alignment hypothesis, which suggests that internal alignments drive branding activity.

H1. Journalists' self-expressed professional identity will align with their use of branding (at individual, organizational, and institutional levels).

H2. Journalists' self-expressed motivations for branding will align with their use of branding (at individual, organizational, and institutional levels).

\section{Method}

Data were collected via an online survey of journalists working in North America (with $90 \%$ of the sample being journalists in the United States, and 10\% in Canada). Journalists were recruited using lists maintained by CisionPoint, the most comprehensive media contacts database in North America. The database was searched for individuals whose job role was listed as reporter, writer, editor, columnist, correspondent, freelance journalist, news director, producer, or blogger, and who also worked at newspapers, television stations, cable stations, radio stations, magazines, news websites, wire services, news blogs, or as freelancers. This survey intended to focus on journalists, so filters were used to include contacts who worked at magazines with circulations above 10,000, newspapers with circulations above 1000, online outlets with at least 10,000 unique monthly visitors, and all those listed as journalists working for wire services, TV and radio stations, and as freelancers. This resulted in a list of 109,843 contacts. This list is obviously overinclusive, but when trying to capture the wide range of work that could be considered as journalism in the 21 st century, this is a better starting point than being underinclusive.

From this list, two samples of approximately 5000 names each were drawn using a random start point and a skip interval of 21 . These contacts were sent email invitations to participate in a survey and were offered the incentive of participation in a random 
drawing for 10 US\$50 gift cards to Amazon.com. To counteract the overinclusive nature of the list, the invitations and the first page of the survey (which contained other disclosure notices) instructed potential participants that this survey was meant for "working journalists" only, and those who did not consider themselves working journalists should not participate. Indeed, several participants emailed the researchers to indicate that they are not working journalists and should be excluded from future mailings, and others wrote that they began the survey before discovering that the questions did not apply to their work, and so withdrew. A total of 10,455 invitations were sent, resulting in 242 partially completed surveys and 642 completed surveys, giving a response rate of $8.9 \%$ (AAPOR, 2016).

Respondents ranged in age from 24 to 61 (mean $(M)=49$ ) years, and $54 \%$ of them reported being male. Most were White (88\%) and employed full-time (73\%), though a significant number worked as freelancers (19\%). Only $11 \%$ had no college degree, $61 \%$ had a bachelor's degree, and 23\% had a master's degree. About half of respondents reported that their degree was in journalism (bachelor's $=49.7 \%$ and master's $=50.7 \%$ ).

\section{Measures}

Building on previous literature, respondents were asked about their social media use, their use of individual, organizational, and institutional branding, and their motivations for practicing journalistic branding. These were followed by standard demographic measures of age, gender, education, and income. Participants were also asked to estimate the number of editorial employees at their organization. Because responses to this question included many small numbers and a few very large ones, responses were re-coded based on quartiles $(\mathrm{Q} 1=1-3, \mathrm{Q} 2=4-10, \mathrm{Q} 3=11-49, \mathrm{Q} 4=50$, and higher). As a result, the organizational size variable ranges from 1 to 4 , with larger numbers indicating larger news organizations.

Social media use. Journalists were asked which social media accounts they have and how often they use them on a scale from 1 (Hardly ever) to 7 (All the time), among the following platforms: Facebook, Twitter, Instagram, LinkedIn, Pinterest, Reddit, and other. Responses to these questions were summed to create a scale of social media use (range $=0-49, M=17.43$, standard deviation $(S D)=9.31$ ).

Journalistic identity. These measures - based on previous qualitative research that suggested different values and beliefs may be influential in how journalists perceive their professional identity in relation to branding activities (Holton and Molyneux, 2017) - to gauge the strength of individual, organizational, and institutional dimensions in shaping a journalist's professional identity. Respondents were asked, "When you think about the factors that have influenced how you identify as a professional journalist, to what extent have the following been influential for you?" Respondents used a 7-point Likert-type scale ranging from "not at all influential" to "extremely influential" to rate the following statements: "My own personal values and beliefs," "The values and beliefs of my current news organization," and "The values and beliefs of the broader profession of journalism" (Appendix 1). 
Table 2. Measures of branding motivations by approach and level $(n=625)$.

\begin{tabular}{|c|c|c|c|c|c|c|c|c|c|c|}
\hline & \multicolumn{3}{|l|}{ Individual } & \multicolumn{3}{|c|}{ Organizational } & \multicolumn{3}{|l|}{ Institutional } & \multirow{2}{*}{$\begin{array}{l}\text { Average } \\
\text { of means }\end{array}$} \\
\hline & & $M$ & $S D$ & & $M$ & $S D$ & & $M$ & $S D$ & \\
\hline \multirow[t]{2}{*}{ Personal } & $\begin{array}{l}\text { Respect and } \\
\text { renown }\end{array}$ & 4.69 & 1.88 & Collegiality & 3.16 & 1.87 & $\begin{array}{l}\text { Support } \\
\text { others }\end{array}$ & 3.44 & 1.90 & 4.00 \\
\hline & Relationships & 5.15 & 1.63 & & & & Collaboration & 3.58 & 1.90 & \\
\hline \multirow[t]{4}{*}{ Professional } & Preserve job & 4.38 & 1.96 & Please boss & 4.12 & 2.09 & Uphold values & 3.61 & 1.96 & 4.34 \\
\hline & $\begin{array}{l}\text { Grow } \\
\text { following }\end{array}$ & 5.12 & 1.82 & $\begin{array}{l}\text { Adhere to } \\
\text { policy }\end{array}$ & 3.55 & 2.07 & $\begin{array}{l}\text { Promote } \\
\text { others }\end{array}$ & 3.86 & 1.90 & \\
\hline & $\begin{array}{l}\text { Increase } \\
\text { value }\end{array}$ & 4.68 & 1.88 & $\begin{array}{l}\text { Attention } \\
\text { to org }\end{array}$ & 5.09 & 1.75 & & & & \\
\hline & & & & $\begin{array}{l}\text { Promote } \\
\text { co-workers }\end{array}$ & 4.64 & 1.94 & & & & \\
\hline \multicolumn{2}{|c|}{ Average of means } & 4.80 & & & 4.11 & & & 3.62 & & \\
\hline
\end{tabular}

Journalists' motivations for branding are felt more strongly at the individual and professional levels. $T$-tests show that differences in average of means for column and row totals are all statistically significant at the $p<.00$ I level.

Branding motivations. Using Table 1 as a guide, respondents were asked, "How influential are the following motivations in your use of branding?" Respondents used a 7-point Likert-type scale ranging from "not at all influential" to "extremely influential" to rate 14 statements mirroring those in Table 1 (e.g. "Branding increases my online following," "Branding pleases my boss," and "Branding encourages collaboration with other journalists"; see Appendix 1 for the complete list of items). These responses were organized into scales based on the divisions in the table by summing responses and dividing by the number of items in the scale. The scale for individual motivations contained five items $(M=4.8, S D=1.54$, alpha $=.90)$; the scale for organizational motivations contained five items $(M=4.11, S D=1.48$, alpha $=.81)$; and the scale for institutional motivations contained four items $(M=3.61, S D=1.62$, alpha $=.87)$.

Journalists were also asked if they feel pressure to develop a personal brand. If they said yes, they were asked about the source of that pressure in an open-ended question. These open-ended responses were analyzed as indicated in the results section.

Branding activity. Branding is a highly idiosyncratic activity that may take many forms depending on the outcomes desired. As such, this study measures the prevalence of branding practices at individual, organizational, and institutional levels by asking how often journalists practice branding, regardless of the specific strategy employed. Journalists were asked how often they "make an effort to develop a personal brand" (i.e. individual level), "promote your news organization's brand" (i.e. organizational level), and "promote the work of journalists outside your news organization" (i.e. institutional level). Responses were measured on a 7-point Likert-type scale ranging from "never" to "all the time." Journalists were also asked to rate the relative importance of their individual and organizational brands, with 1 meaning the individual brand is most important, 
7 meaning the organizational brand is the most important, and 4 meaning both brands are equally important.

Metadata. Survey data were merged with metadata collected from the CisionPoint database. These data included media type (newspaper, television, magazine, radio, online, wire service, and freelancer) and social media accounts associated with the contact. The list of Twitter accounts associated with respondents who completed the survey was batch-scraped using the rtweet package in R to query Twitter's application programming interface (API). This process collected the following data for each account: the number of friends, followers, and posts, as well as the number of days since the individual joined Twitter. Thereafter, the Twitter data were merged with the survey data, but all identifying information (including Twitter handles) was removed from the data prior to analysis.

\section{Results}

To answer the research question about what motivates professional journalists' use of branding, answers to the motivation questions were organized in a chart to match the typology presented in Table 1 . The strongest motivations were developing relationships with the audience $(M=5.15, S D=1.63)$ and growing their personal following $(M=5.12$, $S D=1.82$ ). These both fall in the realm of individual branding. The next highest was attracting attention to their organization $(M=5.09, S D=1.75)$. Overall, individual branding motivations (average $M=4.80$ ) were significantly stronger than organizational and institutional branding motivations (respectively), and professional branding approaches (average $M=4.34$ ) were significantly more influential than personal ones (Table 2).

Another way of looking at this question is by asking where the pressure to practice branding comes from. Following the question about whether journalists feel pressure to create a personal brand, those who answered yes were given an opportunity to write where that pressure was coming from. These open-ended responses were coded by inductively creating categories based on the responses themselves. If more than one source of pressure was listed, only the first was coded (on the assumption that the firstlisted item is the most salient). The first category was labeled "Self" (30\%) and included responses such as me, myself, my needs, and so on. The remarks in this category reflected a desire to "improve myself" and a deep-seated knowledge that branding is individually important and relevant. The second category was labeled "Peers" (22.7\%) and included responses such as competitors, other journalists, others on social media, and so on. The remarks in this category reflected pressure to fit in among comparable professionals. The third category was labeled "Boss" (21\%) and included responses such as my employer, corporate, managers, and so on. Responses in this category reflected pressure from supervisors to employ branding. The fourth category was labeled "Market/Industry" $(18.9 \%)$ and included responses such as the field of journalism, society, social media culture, the market, and so on. These responses reflected a sense that the profession as a whole had shifted in a way that favored those with a personal brand, and so they felt pressured to create one. The final two categories presented in Table 3 consisted only of the words in their titles and constituted only a small fraction of the results (5.1\% combined). Collectively, these results suggest that, for the most part, journalists are feeling implicit 
Table 3. Sources of pressure to develop a personal brand.

\begin{tabular}{lcc}
\hline & Count & Percentage (\%) \\
\hline Self (improving relationships, image, and job prospects) & 70 & 30.0 \\
Peers/competitors (I see others doing it) & 53 & 22.7 \\
Boss (supervisor asked me to) & 49 & 21.0 \\
Market/industry (this is the way the profession is now) & 44 & 18.9 \\
Audience/consumers & 8 & 3.4 \\
Advertisers & 4 & 1.7 \\
Other & 5 & 2.1 \\
\hline
\end{tabular}

pressure (from themselves, their peers, and the market-about $70 \%$ of the responses coded) to develop a personal brand by noticing trends themselves and working to remain current, rather than explicit pressure in the form of a directive from management $(21 \%)$.

Measures of branding at the individual, organizational, and institutional levels were taken by asking respondents how often (on a scale of 1-7) they practiced each level of branding. Paired sample $T$-tests reveal that journalists reported engaging in organizational branding $(M=5.32, S D=1.61)$ significantly more often than both individual $\left(M=4.31, S D=1.92, t=12.69^{* * *}\right)$ and institutional branding $(M=4.37, S D=1.81$, $\left.t=10.89^{* * *}\right)$. No statistically significant difference was found between individual and institutional branding levels. Interestingly, when journalists were asked to rate the relative importance of individual and organizational brands, the plurality of respondents (29\%) indicated "4-both brands are equally important." Slightly more respondents ended up on the organizational side of the scale, bringing the mean to $4.19(S D=1.82)$.

A few other factors (based on self-reported social media use and scraped measures of social media presence) also had an influence on branding activity. Results of regression modeling using these variables are presented in Tables 4 and 5. The scale of self-reported social media use is strongly associated with all levels of branding, except in the case of organizational branding when including motivations in the model. These models also show that organization size is negatively related to individual branding, suggesting that journalists at larger organizations tend to practice less individual branding. Finally, these findings show that organizational branding was associated with older journalists and those with less education in both models.

Bivariate correlations using scraped data on Twitter presence reveal some additional associations. Those journalists following more people were more likely to engage in personal branding $\left(r=.115^{* *}\right)$ and to report personal motivations for branding (the top half of Table $\left.1, r=.143^{* *}\right)$. The number of followers was not related to any motivation constructs or branding activities, suggesting that branding activity is not a function of celebrity. Finally, as would be expected, the larger a journalist's organization is, the more followers they are likely to have $\left(r=.111^{*}\right)$.

As a final means of analyzing what motivates journalists to brand, branding activity at the individual, organizational, and institutional levels was split into low (1-4) and high (5-7) categories for analysis using cross-tabulations. These reveal that in the case of personal branding, those working at newspapers were more likely $(66 \%)$ to have low 
Table 4. The role of identity in predicting levels of journalistic branding.

\begin{tabular}{lccc}
\hline & Individual branding & Organizational branding & Institutional branding \\
\hline Age & .076 & $.123^{*}$ & .029 \\
Gender & $.088^{*}$ & -.041 & .072 \\
Social media use & $.409^{* * *}$ & $.291^{* * *}$ & $.306^{* * *}$ \\
Organization size & $-.165^{* * *}$ & .006 & -.025 \\
Education & -.055 & $-.127^{* *}$ & -.032 \\
Income & .040 & .058 & .079 \\
$\Delta R^{2}(\%)$ & $19.6^{* * *}$ & $7.4^{* * *}$ & $10.4^{* * *}$ \\
Personal identity & $.190^{* * *}$ & -.019 & $.107^{*}$ \\
Organizational identity & .053 & $.303^{* * *}$ & -.055 \\
Institutional identity & -.061 & .011 & $.089^{*}$ \\
$\Delta R^{2}(\%)$ & $4.1 * * *$ & $9.0^{* * *}$ & $1.9 *$ \\
Total $R^{2}(\%)$ & $23.7^{* * *}$ & $16.4^{* * *}$ & $12.3^{* * *}$ \\
\hline
\end{tabular}

$N=532$. Cell entries are ordinary least square (OLS) regression; final-entry standardized coefficients (betas). $* p<.05 ; * *<.01 ; * * * p<.001$.

Table 5. The role of motivations in predicting levels of journalistic branding.

\begin{tabular}{|c|c|c|c|}
\hline & Individual branding & Organizational branding & Institutional branding \\
\hline Age & $.108 * *$ & $.14 I^{*}$ & .047 \\
\hline Gender (female) & .063 & -.045 & .069 \\
\hline Social media use & $.154 * * *$ & .090 & $.255 * * *$ \\
\hline Organization size & $-.129 * * *$ & -.015 & -.001 \\
\hline Education & -.057 & $-.113^{* *}$ & -.030 \\
\hline Income & .010 & .046 & .073 \\
\hline$\Delta R^{2}(\%)$ & $18.8^{* * *}$ & $7.3^{* * * *}$ & $9.8 * * *$ \\
\hline Individual motives & $.544 * * *$ & $.152^{* *}$ & -.022 \\
\hline Organizational motives & -.066 & $.343 * * *$ & -.078 \\
\hline Institutional motives & $.094^{*}$ & .049 & $.255^{* * *}$ \\
\hline$\Delta R^{2}(\%)$ & $24.7^{* * * *}$ & $19.5^{* * *}$ & $4.6 * * *$ \\
\hline Total $R^{2}(\%)$ & $42.5^{* * * *}$ & $26.8 * * *$ & $|4 .|^{* * *}$ \\
\hline
\end{tabular}

$N=532$. Cell entries are ordinary least square (OLS) regression; final-entry standardized coefficients (betas). $* p<.05 ; * * p<.01 ; * * * p<.001$.

branding activity, while those working at blogs were more likely $(75 \%)$ to have high branding activity $\left(\chi^{2}=50.224 * * *\right)$. There were no significant differences across platforms in terms of organizational branding. In terms of institutional branding, those working at newspapers were again more likely (59\%) to have low branding activity, while those working as freelancers were more likely (78\%) to have high branding activity $\left(\chi^{2}=30.927 * * *\right)$.

The two hypotheses investigate the proposition that branding activity aligns with internal identity and motivations, and that these help explain branding activity above and 
beyond the influence of social media use. These hypotheses were tested using regression modeling. Table 4 shows the results for H1, which hypothesized that journalists' selfexpressed professional identity will align with their use of branding (at individual, organizational, and institutional levels). Demographic variables, social media use, and organization size were entered into the first block, with the items measuring the strength of personal, organizational, and institutional journalistic identities in the second block. Those whose journalistic identity was strongly influenced by their personal values and beliefs were more likely to practice branding at the individual level $\left(\beta=.190^{* * *}\right)$, whereas organizational and institutional identities were not significantly related to individual branding. Similarly, those whose journalistic identity was strongly influenced by their organization were more likely to practice branding at the organizational level $\left(\beta=.303^{* *}\right)$, while personal and institutional identities were not significantly related to organizational branding. In the case of institutional branding, both those with strong personal $\left(\beta=.107^{*}\right)$ and institutional identities $\left(\beta=.089^{*}\right)$ were more likely to practice branding at the institutional level, while organizational identity was not significantly related to institutional branding. These results support the branding alignment hypotheses in the case of a journalist's professional identity. It is worth noting that a large portion of the variance in individual branding is explained by individual factors in the first block (primarily higher social media use and smaller organizational size). By contrast, in the case of organizational branding, the measure of professional identity (the second block) explained more variance than did the demographic variables and social media use.

A similar approach was used to test $\mathrm{H} 2$, which hypothesized that journalists' selfexpressed motivations for branding will align with their use of branding (at individual, organizational, and institutional levels). Demographic variables, social media use, and organization size were entered into the first block, with the scales measuring individual, organizational, and institutional motivations for branding (the three columns in Table 1) entered into the second block. Again, there was consistent alignment between motivations and practices (Table 5). Those with strong individual motivations were significantly more likely to practice individual branding $\left(\beta=.544^{* * *}\right)$. The stronger a person's organizational motivations, the more likely they were to practice organizational branding $(\beta=.343 * * *)$, though individual motivations also displayed a weaker connection to organizational branding $(\beta=.152 * *)$. In the case of institutional branding, only institutional motivations were a significant predictor of the level of institutional branding $\left(\beta=.255^{* * *}\right)$. These results provide strong support for the branding alignment hypothesis.

As a further test of the validity of the divisions hypothesized in Table 1, the items measuring motivations were split into personal and professional scales based on the table's two rows rather than its columns. These scales were entered into regression models similar to those presented in Tables 4 and 5, with the same set of controls. As might be expected, personal motivations were positively related to individual branding $\left(\beta=.383^{* * *}\right)$, but not organizational branding. Professional motivations were positively related to organizational branding $(\beta=.571 * * *)$ but not to individual branding. In the case of institutional branding, only personal motivations were significantly related $(\beta=.230 * * *)$. This suggests that both the column and the row divisions in Table 1 are useful distinctions in separating branding motivations into a typology. 
Table 6. Conceptual measures most relevant in explaining branding activities at individual, organizational, and institutional levels.

\begin{tabular}{|c|c|c|c|}
\hline & Individual & Organizational & Institutional \\
\hline $\begin{array}{l}\text { Positive } \\
\text { association }\end{array}$ & $\begin{array}{l}\text { - Gain respect and } \\
\text { renown } \\
\text { - Grow my following } \\
\text { - Preserve my job } \\
\text { - Encourage } \\
\text { collaboration } \\
\text { - } \text { Develop relationships }\end{array}$ & $\begin{array}{l}\text { - Attract attention to } \\
\text { organization } \\
\text { - Promote co-workers } \\
\text { - Develop relationships } \\
\text { - Encourage collaboration } \\
\text { - Uphold journalistic values }\end{array}$ & $\begin{array}{l}\text { - Support other } \\
\text { journalists } \\
\text { - Promote other } \\
\text { journalists }\end{array}$ \\
\hline $\begin{array}{l}\text { Negative } \\
\text { association }\end{array}$ & - Promote co-workers & - Support other journalists & $\begin{array}{l}\text { - Uphold } \\
\text { journalistic values }\end{array}$ \\
\hline
\end{tabular}

Items are listed in order of the strength of their contribution to variance in the dependent variable. The following items were unused in any model: collegiality with co-workers, increase my value, please my boss, and adhere to policy. Models included controls for age, gender, education, income, organization size, and social media use.

Furthermore, because the list of possible motivations for branding has not been used in survey research before, it is possible that not all the items are relevant motivators of journalistic branding activity. To test this possibility, stepwise regression was used to identify which branding motivations were the strongest contributors to each branding practice (Table 6). In this method, the first block of controls is entered, followed by all the branding motivations measured in this study. The item with the strongest relationship to the dependent variable is kept to enter in a second block, and the rest are entered again. This process repeats until all items that contribute to a significant change in $R^{2}$ have been found, and the rest are discarded. The items identified by this process as significant contributors to variance in the dependent variable are listed in the table. In other words, Table 6 displays the factors that are most relevant in influencing respondents' branding activities. The lists are relatively distinct for each level of branding, suggesting that each derives from its own set of motivations. Two items, developing relationships with the audience and encouraging collaboration with other journalists, overlapped in the individual and organizational models. There were four items that did not make a significant contribution to variance in any of the levels of branding. They were the statements that branding encourages collegiality with co-workers, increases my value as a journalist, pleases my boss, and is part of my organization's policy.

\section{Discussion}

The study of journalists' adoption of branding and marketing techniques to promote themselves, their work, their organizations and co-workers, and the broader institution of journalism has become a growing element of the journalism studies literature and a key part of the broader study of media work in the digital age. These studies have relied mainly on interviews and content analyses, and their findings have shown meaningful differences in the levels and functions of branding practices-including some practices 
that have been enforced by organizational policy. This research has focused almost entirely on the context of social media, which has been viewed as a significant driver-if not the driver - of journalists' branding activity. But the literature has hinted that, while social media has proven important terrain for branding, it may not be all that is driving branding among journalists. This study set out to uncover what motivations and influences might be leading journalists to practice individual, organizational, and institutional levels of branding above and beyond the role of social media.

To do this, this study developed a framework for understanding branding motivations and then tested the validity of this framework using the branding alignment hypothesis, which posits that journalists' internal orientations align with their branding activities. This was tested by measuring motivations for branding and the strength of one's individual, organizational, and institutional identities as a journalist. The findings suggest strong support for this alignment hypothesis, with individual identities and motivations having strong relationships to individual branding, and organizational identities and motivations having strong relationships to organizational branding (Tables 4 and 5). In addition, the number of followers was not related to branding activity, suggesting that branding is not a function of celebrity. Journalists reported that they felt individual-level branding motivations most strongly, with organizational motivations in second place and institutional motivations a distant third. They reported that individual and organizational brands alike are important to them, but they practice organizational branding significantly more often.

This clear division sets up two archetypes that can be understood using the idioms "self-made journalist" and "company journalist." These archetypes describe those more entrepreneurial and relational in spirit as compared with those more embedded within and loyal to an organization. Self-made journalists seek recognition, renown, and job security by promoting themselves at the expense of promoting co-workers. Company journalists treat their organization as the focus of attention, promoting their co-workers at the expense of promoting those at other organizations (Table 6). Thus, a key split in identifying both branding activity and motivations for branding is in a journalist's career orientation (self-made or company). Interestingly, company journalists are also older and less formally educated, suggesting that there may be generational differences in journalists' expectations and approach to their careers that shape their use of branding. Future research may ask how long the journalist has been with their current organization to examine whether this career orientation may change as a journalist gains tenure or settles down in one organization.

Psychological factors such as the need for social validation also play an important role in influencing branding activity. This manifests in journalists reporting that they feel peer pressure to practice branding, that the market indicates its importance to them, or that they "just know" it is something they must do. This suggests that what causes journalists to practice branding is more complex and individualized than simply that their boss told them to do so. Bosses were listed as a source of pressure to practice branding (Table 3) but were not a significant motivation in predicting branding activity (Table 6). This may be because, as previous research has suggested (Molyneux and Holton, 2015), journalistic branding developed organically, and organizations only began mandating it once its practice was already widespread. 
Another way to understand the drive to develop journalistic brands is to use the notion of capital, in the generic sense of one's personal resources inherent in skills and networks. For instance, the distinction between self-made journalist and the company journalist is seen in the differences in branding activity by media type. Those at newspapers, the oldest and most established category of media company, practiced less individual and institutional branding. These journalists are able to borrow capital from their organizations. Bloggers, on the other hand, practiced more individual branding, presumably as they seek to build up a reputation and accumulate capital. Freelancers, who are disassociated from even an emerging organization such as a blog, might feel disenfranchised, which explains their higher levels of institutional branding. They seek associations with other journalistsperhaps promoting higher-status journalists in the hopes of attracting attention to themselves - as a way of gathering capital and demonstrating their affiliation to the profession.

This distinction is fundamentally between those who acknowledge the precarity of their news work and are committed to mitigating it through individual branding and those who feel comfortable in their current organization and hope to solidify their place in it through organizational branding. The distinction between self-made and company journalists, then, is one of branding practices, or the seat of the identity they choose to develop and promote. This separation is related to the rise of a group called "entrepreneurial journalists," defined as enterprising risk-takers whose work is characterized by instability (Cohen, 2015; Vos and Singer, 2016). This combination of enterprise and instability may give rise to multiple new journalistic practices, including branding. A "self-made" approach to branding, then, may be a hallmark of an entrepreneurial journalist.

The case of institutional branding is less clear than the individual/organizational dyad. Previous studies suggested that institutional branding may have been a reaction to a cultural crisis in journalism, wherein it is unclear who is a journalist and what news can be trusted. That is, by banding together with other journalists and sharing the best examples of journalistic output, journalists might collectively defend their value as a social institution (Ottovordemgentschenfelde, 2017; Sacco and Bossio, 2017). But our survey finds that institutional branding practices appear to be motivated by desires for networking, rather than a desire to uphold the profession as a whole. That is, journalists who practice institutional branding want to relate to journalists at other organizations while also positioning themselves alongside those journalists in the broader institution of journalism. The results show some overlap between individual and institutional identities in predicting institutional branding, which may actually be reflecting the influence of extroversion or pro-social orientation, neither of which was measured here. Future studies should include these either as controls or independent variables.

This study focused on separating internal identities and motivations from general social media use in explaining journalists' branding practices, but it cannot account for the effects that personality, training, and psychosocial orientation might have. An obvious way of addressing this in future work would be to include journalistic role perceptions but might also include asking about "big four" personality traits or other social attitudes and orientations. This study is also limited in its use of a cross-sectional survey, which cannot establish causality. Still, it can be inferred that inherent traits such as identity precede action and that motivations, by definition, also precede action. The survey experienced a high rate of nonresponse, apparently complicated by some organizational 
policies prohibiting participation in surveys of journalists, according to several responses from journalists invited to participate. Even so, the sample is large enough to observe significant associations among theoretical constructs, and it does not differ from the population from which it was drawn in systematic ways, enabling our data to provide strong evidence of the branding alignment hypothesis in the real-world.

This study offers a new way of understanding the challenges of impression management in the social media era. Amid the growing insecurity of media work generally and the particular pressures of branding oneself as well as promoting one's employer online (Duffy and Schwartz, 2017), our research introduces a framework through which to interpret the influences - internal and external - that shape how and why media professionals might engage in branding practices. In particular, this study makes three key contributions to the literature on journalism and branding as well as the larger concern for what it means to be a media worker. First, it presents a first-of-its-kind survey of a broad cross-section of journalists on the factors, both environmental and social-psychological, that contribute to journalists' perceptions of and practices toward branding and promotion work. Second, this study proposes, tests, and confirms a branding alignment hypothesis based on a typology of branding orientations and motivations that establishes and labels the array of influences that journalists feel as they engage in branding and promotion. And, third, whereas previous research has largely assumed that branding activity and social media use are inextricably linked, this study controls for social media activity and thereby demonstrates the forces and factors that influence branding over and above social media engagement alone. In the future, as the pressures to brand oneself and one's organization likely increase, more attention is needed to interpret the contexts of such obligations and their related consequences for journalism and public life.

\section{Funding}

The author(s) received no financial support for the research, authorship, and/or publication of this article.

\section{Note}

1. To be sure, social media platforms have distinct affordances and cultural expectations that influence user behaviors differently (Bucher and Helmond, 2017). Nevertheless, because it is impossible to tease apart exactly how a given journalist will use a given platform relative to another journalist on the same platform, the contribution of this study is in acknowledging and accounting for more than just the oft-studied Twitter platform - recognizing how branding practices may be related to a broader set of social media activity.

\section{ORCID iDs}

Logan Molyneux (iD https://orcid.org/0000-0001-7382-3065

Seth C Lewis (iD https://orcid.org/0000-0001-7498-0599

\section{References}

American Association for Public Opinion Research (AAPOR) (2016) Standard Definitions: Final Dispositions of Case Codes and Outcome Rates for Surveys. 9th ed. Oakbrook Terrace, IL: AAPOR. 
Banks M and Hesmondhalgh D (2009) Looking for work in creative industries policy. International Journal of Cultural Policy 15(4): 415-430.

Berkowitz D (ed.) (1997) Social Meanings of News: A Text-Reader. Thousand Oaks, CA: SAGE.

Bourdieu P (1986) The forms of capital. In: Richardson J (ed.) Handbook of Theory and Research for the Sociology of Education. Westport, CT: Greenwood Publishing, pp. 241-258.

Breed W (1955) Social control in the newsroom: a functional analysis. Social Forces 33(4): 326-335.

Brems C, Temmerman M, Graham T, et al. (2017) Personal branding on Twitter. Digital Journalism 5(4): 443-459.

Bucher T and Helmond A (2017) The affordances of social media platforms. In:Burgess JE, Poell T and Marwick A (eds) The SAGE Handbook of Social Media. London: SAGE, pp. 223-253.

Bunce M (2017) Management and resistance in the digital newsroom. Journalism. Epub ahead of print 3 February. DOI: 10.1177/1464884916688963.

Carlson M (2017) Journalistic Authority: Legitimating News in the Digital Era. New York: Columbia University Press.

Carlson M and Lewis SC (eds) (2015) Boundaries of Journalism: Professionalism, Practices and Participation. London: Routledge.

Cohen NS (2015) Entrepreneurial journalism and the precarious state of media work. South Atlantic Quarterly 114(3): 513-533.

Creech B and Nadler AM (2017) Post-industrial fog: reconsidering innovation in visions of journalism's future. Journalism 19(2): 182-199.

Deuze M(2005) What is journalism? professional identity and ideology of journalists reconsidered. Journalism: Theory, Practice \& Criticism 6(4): 442-64. DOI: 10.1177/1464884905056815.

Deuze M (2007) Media Work. London: Polity.

Deuze M and Witschge T (2018) Beyond journalism: theorizing the transformation of journalism. Journalism 19(2): 165-181.

Duffy BE and Schwartz B (2017) Digital “women's work?” Job recruitment ads and the feminization of social media employment. New Media \& Society 20: 2972-2989.

Ekdale B, Singer JB, Tully M, et al. (2015) Making change: diffusion of technological, relational, and cultural innovation in the newsroom. Journalism \& Mass Communication Quarterly 92(4): 938-958.

Gandini A (2016) Digital work: self-branding and social capital in the freelance knowledge economy. Marketing Theory 16(1): 123-141.

Gill R (2010) Life is a pitch: managing the self in new media work. In:Deuze M (ed.) Managing Media Work. London: SAGE, pp. 249-262.

Hanusch F and Bruns A (2017) Journalistic branding on Twitter. Digital Journalism 5(1): 26-43.

Hedman U (2015) J-Tweeters: pointing towards a new set of professional practices and norms in journalism. Digital Journalism 3(2): 279-297.

Hedman U (2017) Making the most of Twitter: how technological affordances influence Swedish journalists' self-branding. Journalism. Epub ahead of print 5 October. DOI: $10.1177 / 1464884917734054$.

Hesmondhalgh D and Baker S (2011) Creative Labour: Media Work in Three Cultural Industries. London: Routledge.

Holton AE and Molyneux L (2017) Identity lost? The personal impact of brand journalism. Journalism 18(2): 195-210.

Lewis SC (2012) The tension between professional control and open participation: journalism and its boundaries. Information, Communication \& Society 15(6): 836-866.

Lewis SC and Zamith R (2017) On the worlds of journalism. In:Boczkowski and Anderson CW (eds) Remaking the News: Essays on the Future of Journalism Scholarship in the Digital Age. Cambridge, MA: MIT Press, pp. 111-128. 
Lough K, Molyneux L and Holton AE (2018) A clearer picture: journalistic identity practices in words and images on Twitter. Journalism Practice 12(10): 1277-1291. DOI: 10.1080/17512786.2017.1389292.

Marwick AE (2013) Status Update: Celebrity, Publicity, and Branding in the Social Media Age. New Haven, CT: Yale University Press.

Molyneux L and Holton A (2015) Branding (health) journalism: perceptions, practices, and emerging norms. Digital Journalism 3(2): 225-242.

Molyneux L, Holton A and Lewis SC (2017) How journalists engage in branding on Twitter. Information, Communication \& Society 21: 1386-1401.

Nelson JL (2018) The elusive engagement metric. Digital Journalism 6(4): 528-544.

Ottovordemgentschenfelde S (2017) Organizational, professional, personal: an exploratory study of political journalists and their hybrid brand on Twitter. Journalism 18(1): 64-80.

Pitcan M, Marwick AE and boyd D (2018) Performing a vanilla self: respectability politics, social class, and the digital world. Journal of Computer-Mediated Communication 23(3): 163-179.

Powers M and Vera-Zambrano S (2018) How Journalists use social media in France and the United States: analyzing technology use across journalistic fields. New Media \& Society 20(8): 2728-44. DOI: 10.1177/1461444817731566.

Rettberg JW (2014) Seeing Ourselves Through Technology: How We Use Selfies, Blogs and Wearable Devices to See and Shape Ourselves. New York: Palgrave Macmillan.

Rettberg JW (2018) Self-representation in social media. In: Burgess JE, Marwick A and Poell T (eds) The SAGE Handbook of Social Media. London: SAGE, pp. 429-443.

Russo TC (1998) Organizational and professional identification. Management Communication Quarterly 12(1): 72-111. DOI: 10.1177/0893318998121003.

Sacco V and Bossio D (2017) Don't tweet this! How journalists and media organizations negotiate tensions emerging from the implementation of social media policy in newsrooms. Digital Journalism 5(2): 177-193.

Schultz I (2007) The journalistic gut feeling. Journalism Practice 1(2): 190-207.

Shoemaker PJ and Reese SD (2013) Mediating the Message in the 21st Century: A Media Sociology Perspective. New York: Routledge.

Singer J (2015) Out of bounds: professional norms as boundary markers. In:Carlson M and Lewis SC (eds) Boundaries of Journalism: Professionalism, Practices and Participation. Oxford: Routledge, pp. 21-36.

Tandoc EC and Oh S-K (2017) Small departures, big continuities? Norms, values, and routines in The Guardian's big data journalism. Journalism Studies 18(8): 997-1015.

Tandoc EC and Vos TP (2016) The journalist is marketing the news. Social media in the gatekeeping process. Journalism Practice 10(8): 950-966.

Vos TP and Singer JB (2016) Media discourse about entrepreneurial journalism: implications for journalistic capital. Journalism Practice 10(2): 143-159.

\section{Author biographies}

Logan Molyneux is an assistant professor of journalism at Temple University's Klein College of Media and Communication. His research focuses on journalistic practice, especially relating to mobile and social media. He also studies changing habits of news consumption and the ways in which emerging media technologies shape communication and public life.

Seth C Lewis is the founding holder of the Shirley Papé Chair in Emerging Media in the School of Journalism and Communication at the University of Oregon, Vice Chair of the Journalism Studies Division of the International Communication Association (ICA), and an affiliated fellow of the Yale Information Society Project. His present research focuses on algorithms and automation in 
journalism, the interplay of journalists and audiences, and questions of news, knowledge, and trust in an era of disinformation. In 2013 and 2016, he received ICA's award for Outstanding Article of the Year in Journalism Studies.

Avery E Holton is an associate professor and Vice President's Clinical and Translational Scholar at the University of Utah, where his research and project developments focus on the intersections of journalism, digital and social media, and society. He also was selected as a 2018 National Humanities Center Summer Fellow and will serve in 2019 as an Oslo Metropolitan's Digital Journalism Research Fellow. He was awarded the 2018 Rising Star in Humanities Award by the University of Utah and is part of a \$3.8 million National Institutes of Health study through which he also serves as a research mentor for undergraduate research students with disabilities.

\section{Appendix I}

When you think about the factors that have influenced how you identify as a professional journalist, to what extent have the following been influential for you? $(1=$ not at all influential, $7=$ extremely influential).

A. My own personal values and beliefs.

B. The values and beliefs of my organization.

C. The values and beliefs of the broader profession of journalism.

How influential are the following motivations in your use of branding? $(1=$ not at all influential, $7=$ extremely influential).
A. Branding helps preserve my job.
B. Branding increases my online following.
C. Branding increases my value as a journalist.
D. Branding helps me gain respect and renown.
E. Branding helps me develop relationships with audiences.
F. Branding pleases my boss (i.e. editor/publisher).
G. Branding is a part of my organization's policy.
H. Branding helps me develop collegiality with my co-workers.
I. Branding attracts attention to my organization.
J. Branding helps promote what other reporters at my organization are doing.
K. Branding upholds journalistic values.
L. Branding helps promote what other journalists in the field are doing.
M. Branding encourages collaboration with other journalists.
N. Branding supports journalists at other organizations. 